\title{
Factors Affecting Implementation of Green Supply Chain Management In Tech Manora Packing: a Case Study
}

\author{
Jagannath Reddy ${ }^{1}$, Jagadish ${ }^{2}$, Charanraj. $\mathbf{N}^{3}$, Praveen M.N ${ }^{4}$, Y. D. Sai Rohith ${ }^{5}$, Sathish Kumar. ${ }^{6}$ \\ ${ }^{1}$ Assistant Professor, Department of Mechanical Engineering RLJIT-Doddaballapur \\ ${ }^{2}$ Assistant Professor, Department of Mechanical Engineering NIT-Silchar, Assam \\ ${ }_{3,4,5,6}$ Students, Department of Mechanical Engineering RLJIT-Doddaballapur \\ *Correesponding Author Email: ${ }^{1}$ jrreddy.mech@gmail.com, ${ }^{2}$ jagadishbaridabad.s@gmail.com, ${ }^{3}$ charanraj.n45@gmail.com, \\ ${ }^{4}$ praveenmnpravi96@gmail.com, ${ }^{5}$ rohith.ydsr@gmail.com, ${ }^{6}$ sathishkumar.b7464@gmail.com
}

\begin{abstract}
The concept of Green Supply Chain Management (GSCM) is achieving high level implication that can help to reduce the harmful effect of manufacturing activities on the environment. The prime objective is to identify the factors affecting implementation of green supply chain management in Tech Manora packing industry. The collection of data combined primary and secondary sources, the primary source of data is approaching with industry expert by questionnaires. The secondary source of data that is published articles related to GSCM. This study exposed that the most prominent factors affecting implementation of green supply chain management in Tech Manora industry, including lack of knowledge, top management commitment, high cost investment, lack of Government support, lack of information Technology, lack of learning capacity to evaluate GSCM. Finally this study recommends that tech menorah packing industry and its partners should organize joint seminars and workshops to sensitize the staff and suppliers on the benefits of green supply chain management. Further this study will help to the small scale industries to understand the factors affecting while implementation of GSCM.
\end{abstract}

Key words: Green Supply chain Management, environmental management, factors affecting GSCM.

\section{Introduction}

The term green supply chain management mainly refers to those concepts which integrate the sustainable environmental processes into the outmoded supply chain. This process can include product design, manufacturing, production, material sourcing, and end of life management. According to this definition, GSCM refers to a wide range of products from product design by recycling or destroy. In this process, the products are passed through a cycle of life. For example, as same as human beings, they also pass through the cycle of life such as birth, maturity, and death. The product life cycle involves a degree of structure to the life of products which provide the directions for the functional efforts to produce and deliver the product[1].

The developing issues in the worldwide market for green concerns and the shortage of natural resources have constrained officials to observe supply chain systems from an environmental point of view. Industries with high environmental risks, including automotive, chemical, plastic, and heavy manufacturing, have continuously considered advancements in environmental performance by way of one of the essential competitive needs, adjoining lower costs, lead-time, and quality. Green supply chain management (GSCM) is a developing field inspired by the requirement for environmental awareness[1].

GSCM and traditional SCM techniques are highly different at various levels of working from manufacturing to reverse logistics. Traditional SCM is commonly driven by the lone agenda of the economy as its critical objective while GSCM takes into consideration both the environmental as well as economic intentions. SCM out rightly discards eco-friendly techniques whereas GSCM stresses green, combined and environmentally improved practices. Customary SCM is extra dedicated on controlling the final manufactured goods, with no concern for the resultant harmful properties on the atmosphere during distribution and manufacturing.

\section{Literature Review}

Green supply chain management is attaining reputation among operation executive mainly with those who are following the ecofriendly performance of their operation. GSCM had a large and random boom in theoretical journals over the last few decades, in particular throughout the late 1980's and early 1990's changing from specially sensible and theoretical improvements in practical and theoretical studies[2][3]. Earlier research specified that the virtual significance of these practices can be absolutely outlined the commencing of environmental management movement throughout the late 1960's [15]. The GSCM thinking remains extensive and there is no appropriate definition to describe it. Meanwhile the concept is explained in another way through researches, and it is challenging to define green supply chain by using a single definition[4][6].

The implementation of GSCM produces many positive aspects at industrial Framework, which can be listed as: growth of ecological enhancement, lowest scrap production, cost saving resulting in enhanced returns and etc. The purpose of green supply resources in the supply chain also helps in enhancing the accepted skill 
ability of business and their allies. Moreover, an eco friendly execution of $\mathrm{gscm}$ is in any business Enterprise plays a fundamental function in procuring and keeping positive factors[14]. Thus, several researches had made it obvious in their work and the gscm execution is very indispensable and end result concerned with the ecological components of the industry.

To cope with a range of ecological and social impacts and challenges inspired by earning and some other industries sustainable supply chain plays a prominent role and therefore the beginning and execution of sustainability in supply chain management remains growing.[5][4][6]. Sustainability in supply chains clearly deals with the issues related to the ecological, Social and economic components on wide[7], which is also supported by the "triple bottom line" thinking to retain exchange between the ecological, social and economic overall performance of business[8] [9][10][11][12][13].

\section{Activities in Green Supply Chain Management}

\section{i) Green purchasing}

Green purchasing is described as an ecologically buying resource that tries to make sure that recruit products meet ecological needs set by the means of procuring firm, such as minimizing the generation of waste, stimulating recycling, remanufacturing, resource saving and replacement of substances[22]. Green purchasing is the approach whereby ecological and social deliberations are considered with equivalent to the cost, quality and performance measures green purchasing reduces harmful ecological and social outcomes with the use of natural resources. Green purchasing helps to maximize the resource efficiency.

\section{ii) Green design}

Green design is similarly called as ecological design. Basically it is the way of designing physical objects, and offerings to fulfill with the concepts of ecological sustainability. It is about designing a products that encourages ecological consciousness. In the complete life cycle process of the product, the company have to make complete consideration of the quantity, quality and price of the product, consequently achieving the least resource intake and high ecological friendliness[23].

\section{iii) Green manufacturing}

Green manufacturing process consists of a lot of interior and exterior factors. Now-a-days, manufacturing process for involving into a new standards. The most important motive of green manufacturing is decreasing the energy and material expectation in manufacturing process, and also reduces the quantity of scrap indirectly[25].

\section{iv) Green distribution}

Green distribution is described any suggest of transportation between dealers and Consumers with lowest feasible effect on the natural and social environment. And comprises of complete sharing technique from storage, order processing, packaging picking, enhanced vehicle loading's, transport to the consumers and taking again for packing[25].

\section{v) Green packaging}

Packaging is very important to the industry for reaching its ecological objectives. However it obliges definite needs linked to the distribution of the product, it is now not the phase of proper carrier presented through the product. It may effects environment in some cases by[30].

\section{vi) Green Marketing}

By implementing information technology GSCM, green marketing refers completely to the up gradation of products with ecological features, in general Green Marketing in much wider idea which must incorporate products adjustment, modifications to the production process, packaging modification as well as changes in the marketing. Green Marketing consists of improving brand image as most efficient way than any other[26].

\section{vii) Reverse Logistics}

Reverse logistics has many faces. It can be consumers returns, marketing returns assets returns, damage returns, return avoidance, gate-keeping and many other types of issues. it is clear that good reverse logistics management helps keep customers happy by reducing their risk and ensuring the corporation will continue to have a long-term relationship with its consumers[31].

\section{Case Study}

\section{i) Company Profile:}

Tech Manora Packaging Industry established in 2011 at Madakasira, Ananthapur district, Andhra Pradesh, India. An intention to manufactures of corrugated boxes. We are commercial enterprise group concerned in manufacturer and supplier of high quality sustainable corrugated boxes. We have been working with the many customers are The Karnataka mango, ANR Fresh world, Legend Packaged Drinking Water, GNS Gold, RBD, Palmolien oil. Tech Manora Packaging Industry manufactures printed, plain, 5 panel folder, slotted type boxes, rigid type, partition type boxes etc. With a well-trained man power of 25 , the unit is built on $10,000 \mathrm{Sq}$. Ft. The current income stands at 2 Crores per annum, $20 \%$ of which is exported. The company is ISO $9001-2008$ certified and it adheres $100 \%$ to the norms of Total Quality management. In order to attain the goals of this case study, some interactions are done with Production Manager and Skilled operators to know the important details and information about the manufacturing of corrugated packing boxes and issues dealing with all through the operation. The factors affecting implementation of Green Supply Chain Management are listed in the following table1.

\section{ii) Factors affecting Green Supply Chain implementation :}

Organisation in competitive world make a desired prior in making a decision to enforce an ecological plan. Organisations will experience benefits like positive image, markets hare, and efficiency positive aspects through implementing environmental initiatives. evertheless, there are only cost and benefit related troubles concerned at the system of imposing the ecological practices. [17] Explained their view about pressure organizations as the elements influencing GSCM into two: exterior pressure for instance controllers, consumers, suppliers; and internal pressures for occasion shareholders ,administration, and workers. [19] in addition written that understanding capability is expanded by means of self-learning, job training, and nonstop practice of professional skills.Moreover, corporation's skills are carefully int erconnected to ecological performance, and practical ecological practices are adopted by using corporations with larger capabilities. The study on pressures in China [18] explained the fine techniques for the adoption of GSCM practices. Mainly training of consumers in public and non-public enterprises want to emerge as extra wide spread in incorporating GSCM elements. On the factors affecting Green Supply Chain of the manufacturing industries, discussions were concluded on the following factors: 
lack of knowledge and expertise involving Green Supply Chain; lack of awareness of the practicable financial advantages of green supply chain; lack of learning capability to evaluate green supply chain; high price of the environmental applications have an effect on green supply chain; uneconomical recycling and reusing of wastes affect green supply chain; unwilling to implement the rules involving environmental coverage with the aid of policy makers; lack of organisation commitment affect green supply chain; lack of management dedication effect on green supply chain; lack of companywide environmental standards. These factors set up or supported through [16] on budget and benefits involving implementation of the ecological plan, [20] lack of expertise, [21] on administrative and practical tools. Table 1: factors affecting implementation of gscm in tech manora packing industry

\begin{tabular}{|c|c|c|}
\hline Sl.No. & Factors affecting & Description \\
\hline \multicolumn{3}{|c|}{ Government policies and regulations(GPR) } \\
\hline 1. & Lack of government support & $\begin{array}{l}\text { Government instructions can debilitate the selection of activities, as they set the } \\
\text { controls for the business. }\end{array}$ \\
\hline 2. & Local environmental regulations & $\begin{array}{l}\text { Local environmental regulations are important to promote environmental } \\
\text { performance. }\end{array}$ \\
\hline 3. & $\begin{array}{l}\text { Lack of moral standards and company social } \\
\text { responsibility }\end{array}$ & Many groups don't have high moral values and accountability. \\
\hline \multicolumn{3}{|c|}{ Customers $(C)$} \\
\hline 4. & Lack of awareness in the society & $\begin{array}{l}\text { Unawareness in society skill that clients are nevertheless unaware } \\
\text { of inexperienced products. }\end{array}$ \\
\hline 5. & Lack of demand and public awareness & Lack of consciousness by customers about the advantages of green products. \\
\hline \multicolumn{3}{|c|}{ External factors $(E F)$} \\
\hline 6. & Lack of knowledge to implement green buying & $\begin{array}{l}\text { The business enterprise can't put in force inexperienced shopping for due to lack } \\
\text { of perception. }\end{array}$ \\
\hline 7. & Improper organization structure & $\begin{array}{l}\text { Organizations are unable to adopt GSCM due to their improper } \\
\text { organizational shape. }\end{array}$ \\
\hline 8. & Transportation price & Transportation price effects due to rising fuel prices. \\
\hline \multicolumn{3}{|c|}{ Financial factors $(F F)$} \\
\hline 9. & Cost for disposal of hazardous materials & $\begin{array}{l}\text { Industry has responsibility in bringing down price for discarding waste } \\
\text { and detrimental material. }\end{array}$ \\
\hline 10. & High costs & $\begin{array}{l}\text { Projects prices are high in the execution of inexperienced practises, for example, } \\
\text { eco design, and green assembling. }\end{array}$ \\
\hline 11. & Payment delays & The payments may delay due to late customer billing. \\
\hline \multicolumn{3}{|c|}{ Production and operational factors $(\mathrm{POF})$} \\
\hline 12. & Lack of administration commitment & Lack of commitment is a key barrier affecting GSCM implementation. \\
\hline 13. & $\begin{array}{l}\text { Lack of professional human sources in the } \\
\text { implementation of GSCM }\end{array}$ & $\begin{array}{l}\text { GSCM can't be correctly applied until the industry has the knowledgeable } \\
\text { human resource for it. }\end{array}$ \\
\hline 14. & Unwilling to modify business strategies & Industries are unwilling to change their old plans and data. \\
\hline 15. & Lack of information technology & $\begin{array}{l}\text { Lack of statistics technological know-how make it difficult to reap environment } \\
\text { friendly GSCM. }\end{array}$ \\
\hline 16. & Lack of training & Lack of training to staffs is a fundamental element affecting GSCM. \\
\hline 17. & Lack of maintenance and service & A regular maintenance for machines is required. \\
\hline
\end{tabular}

\section{Conclusion \& Future Work}

This case study identified the factors affecting GSCM initiatives at Tech Manora Packaging Industry. Using literature and expert's inputs, five main factors and seventeen sub factors are listed, which affects the implementation of successful GSCM. In order to attain the objectives of this case study, semi-structured interviews have been performed with Production Manager and Skilled operators. this study will help for small-scale industry people to implement GSCM and the future scope for researchers to analyze and mitigate these kinds of risks to reduce environmental impacts and improves the operational performances.

\section{Acknowledgements}

Thank you to those experts who offered their comments, tie and opinions on Green Supply Chain Management. We appreciated their support and help. Our sincere thanks to Principal and HOD (Mechanical Engineering) RLJIT, and finally thanks to Tech Manora Packaging Industry, Production Manager those who helped directly and indirectly.

\section{References}

[1] Harleen Kaur, Dr.chandan deep singh "Achieving excellence through green supply chain management in manufacturing industries". Publisher: BookRix (11 January 2018).

[2] Srivastava, S.K., (2007) "Green supply-chain management: a stateof-the-art literature review", International Journal of Management Reviews, Vol. 9, No. 1, pp 53-80.

[3] Seuring, S., and M. Müller. 2008. "Core Issues in Sustainable Supply Chain Management: A Delphi Study.” Business Strategy and the Environment 17 (8): 455-466.

[4] Payman Ahi, Cory Searcy. Article in Journal of Cleaner Production 52:329-341 . August 2013 with 493 Reads. DOI: 10.1016/j.jclepro.2013.02.018

[5] Chaabane, A., Ramudhin, A., \& Paquet, M. (2011). Designing supply chains with sustainability considerations. Production Planning and Control: The Management of Operations, 22(8), 727741.

[6] P Ahi, C Searcy. Journal of cleaner production 52, 329-341, 2013. 476,2013 
[7] Linton, J. D., Jayaraman, V., \& Klassen, R. (2007). Sustainable supply chains: An introduction. Journal of Operations Management, 25(6), 1075-1082.

[8] Elkington, J. (2004). Enter the triple bottom line. In A. Henriques \& J. Richardson (Eds.), the triple bottom line: Does it all add up? (pp. 1-16). London: Earthscan.

[9] Ciliberti, F., Pontrandolfo, P., \& Scozzi, B. (2008). Investigating corporate social responsibility in supply chains: A SME perspective. Journal of Cleaner Production, 16(15), 1579-1588.

[10] Seuring, S., Sarkis, J., Muller, M., \& Rao, P. (2008). Sustainability and supply chain management - an introduction to the special issue. Journal of Cleaner Production, 16(14), 1545-1551.

[11] Font, X., Tapper, R., Schwartz, K., \& Kornilaki, M. (2008) Sustainable supply chain management in tourism. Business Strategy and the Environment, 17(4), 260-271.

[12] M Pagell, Z Wu. Journal of supply chain management 45 (2), 37 56, 2009. 851, 2009

[13] Wolf, J. (2011). Sustainable supply chain management integration: A qualitative analysis of the German manufacturing industry. Journal of Business Ethics, 102(2), 221-235.

[14] Zhu, Q., Sarkis, J. and Geng, Y. Green Supply Chain Management in China: Pressures, Practices and Performance. International Journal of Operations and Production Management 2005, 25(5): 449-468.

[15] Sarkis, J., Zhu, Q. and Lai, K. H. An organizational theoretic review of green supply chain management literature. International Journal of Production Economics 2011, 130(1): 1-15.

[16] Chang, B., Y., Kenzhekhanuly Y., \& Park, B., (2013). A Study on Determinants of Green Supply Chain Management Practice International Journal of Control and Automation Vol. 6, No. 3,

[17] Henriques, I. \& Sadorsky, P. (1996). The Determinants of an Environmentally Responsive Firm: An Empirical Approach. Journal of Environmental Economics and Management, 30, 381 395.

[18] Zhu, Q., Sarkis, J., Cordeiro, J.J. \& Lai, K., (2008) "Firm-level correlates of emergent green supply chain management practices in the Chinese context", Omega, 36, pp 577-591.

[19] Russel, T (Ed.). (1998). Greener Purchasing - Opportunities and Innovation: Greenleaf Publishing.

[20] Christensen, L., \& Staalgaard, P., (2004. Support for purchasing and follow-up of green textiles business-to-business (in Danish). No 9022004 - Danish Ministry of the Environment Environmental Protection Agency.

[21] Walker, H, Di Sisto, L, \& McBain, D. (2008). Drivers and barriers to environmental supply chain management practices: Lessons from the public and private sectors. Journal of Purchasing and Supply Management, 14(1), 69-85.

[22] (Carter et al., 1998; Min and Galle, 2001; Zsidisin and Siferd, 2001).

[23] Jiang Ying, Zhou Li-jun - Study on Green Supply Chain Management Based on Circular Economy. (2012 International Conference on Solid State Devices and Materials Science)

[24] Anoop A.T., Dr. Regi Kumar V., A review of GSCM issues in Indian bottle water industry,Kerala,India,2013

[25] B. Linnhoff, Chemical Engineering Research and Design, vol. 71, pp.503-522, 1993.

[26] M. J. Polonsky, Electronic Green Journal, vol. 1, pp. 1-10, 1994.

[27] Schulte, Dr. Christoph (1999). Logistik. München: Verlag Vahlen. pp. 371-414. ISBN 3-8006-2454-0.

[28] Belz; et al. (2009). Sustainability marketing: a global perspective. The Atrium, Southern Gate, Chichester, West Sussex, UK: John Wiley \& Sons Ltd. ISBN 978-0-470-51922-

[29] Dowlatshahi, S. (2000), "Developing a thepry pf reverse logistics", Interfaces, Vol. 30 No. 3, pp. 143-55. Carter, C. R. and Ellram, L. M (1998), "Reverse Logistics: A review of the literature and frame work for future investigation", Journal of business logistics, Vol. 19 No. 1, pp. 85-102.

[30] Samir K. Srivastava, Green supply-chain management: A state-of the-art literature review,International Journal of Management Reviews (2007).

[31] An executives guide to reverse logistics : by curtis greve and jerry davis. 